\title{
ANALIZA RESPONSYWNOŚCI STRON INTERNETOWYCH POLSKICH BIBLIOTEK UNIWERSYTECKICH
}

\begin{abstract}
The paper presents the results of analysis on eighteen Polish university libraries websites. The subject of study was the website responsiveness regarding the level of their mobile-friendliness in terms of content alignment to mobile devices display capabilities.
\end{abstract}

Słowa kluczowe: mobilność, r esponsywność, ur ządzenie mobilne, strona internetowa, biblioteka

\section{Wstęp}

Z udostępnionego w styczniu 2017 r. i przygotowanego przez firmy We Are Social i Hootsuite raportu Digital in 2017 Global Ovierview wynika, że aktualna liczba użytkowników smartfonów to ponad cztery miliardy dziewięćset milionów użytkowników, czyli 66\% całej populacji ludzi (w Polsce 74\% mieszkańców) ${ }^{1}$. Użytkownicy, którzy wykorzystują te urządzenia do obsługi mediów społecznościowych, to niemal dwa miliardy pięćset pięćdziesiąt milionów osób (34\% całej populacji). W Polsce wskaźnik ten wynosi 31\% mieszkańców. Warto zauważyć, że od lutego 2016 r. nastąpił wzrost liczby użytkowników posługujących się urządzeniami mobilnymi (o 5\%), jak również wykorzystujących te narzędzia do obsługi mediów społecznościowych (o 30\%); 50,3\% dostępnych dzisiaj stron internetowych jest otwierana za pomocą smartfona (w 2016 r. wskaźnik ten wynosił 43,6\% a w 2015 - 35,1\%). Większość użytkowników korzystało przy tym z urządzeń obsługiwanych przez system operacyjny Android (prawie 72\%).

Na podstawie przywołanych danych widać wyraźnie dynamiczny wzrost liczby użytkowników, którzy aktywnie korzystają na co dzień ze smartfonów

\footnotetext{
${ }^{1}$ Dane pochodzą z dokumentu We Are Social, Digital in 2017 Global Overviev, https:// www.slideshare.net/wearesocialsg/digital-in-2017-global-overview, [dostęp: 10.04.2017].

${ }^{2}$ Ibidem.
} 
i tylko od ich chęci, posiadanych i rozwijanych kompetencji (informacyjnych czy informatycznych) zależy w jaki sposób te cyfrowe technologie będą stosowane. Możliwości jest sporo. Od generowania multimedialnych treści, komunikacji z innymi (także w formie wideo) przez tworzenie zasobów dostosowujących się automatycznie do wielkości ekranów urządzeń przenośnych, tworzenia oprogramowania (w tym zwłaszcza mobilnych aplikacji), aż po aspekt wykorzystania tych urządzeń w kontekście wirtualnej i rozszerzonej rzeczywistości. Dzisiaj telefony komórkowe, poza podstawowymi ich funkcjami służącymi do komunikacji głosowej, są wyposażone w podobne właściwości, jak osobiste komputery. Precyzując, są w pewnym sensie komputerami wyposażonymi w procesor, pamięć wewnętrzną i zewnętrzną, kartę graficzną, wyświetlacze dotykowe o rozmaitych parametrach i możliwościach ${ }^{3}$. Mobilność urządzeń staje się też od pewnego czasu czymś zupełnie naturalnym, także w odniesieniu do wyszukiwania, pozyskiwania, gromadzenia, udostępniania i wreszcie zapoznawania się $\mathrm{z}$ różnymi zasobami informacyjnymi, w tym również oczywiście prasą czy książkami.

\section{Mobilne i responsywne strony WWW}

Rozwój technologii mobilnych spowodował, że dzisiaj mamy coraz częściej do czynienia z przystosowaniem stron internetowych do potrzeb użytkownika, który korzysta z urządzeń przenośnych odznaczających się stosunkowo niewielkimi rozmiarami wyświetlaczy. Celem tej optymalizacji jest komfortowe zapoznawanie się $\mathrm{z}$ treściami udostępnionymi na łamach danej witryny niezależnie od tego, czy użytkownik korzysta z tradycyjnego komputera i monitora, tabletu czy też smartfona.

Strona mobilna może występować jako strona dedykowana oraz witryna responsywna przygotowana zgodnie z technologią Web Responsive Design. Pierwszy przypadek dotyczy sytuacji, kiedy twórca strony przygotowuje na przykład mobilny odpowiednik pełnej wersji witryny, z której zasobami zazwyczaj zapoznajemy się za pośrednictwem tradycyjnego komputera czy laptopa. Mobilna, dedykowana wersja strony to zatem witryna przygotowana tylko z myślą o użytkownikach przeglądających sieciowe treści na ekranie smartfona czy tabletu. $\mathrm{Z}$ technicznego punktu widzenia jest to zupełnie odrębna witryna od wersji standardowej (pełnej, desktopowej). Odznacza się w większości przypadków inną architekturą informacji, sposobem nawigacji, ilością udostępnianych na jej łamach treści, ale także zazwyczaj innym adresem WWW. Domena tej takiej witryny jest $\mathrm{w}$ tym przypadku często poprzedzona literą „m”

\footnotetext{
2017, s. 12.
}

${ }^{3}$ G. Gmiterek, S.D. Kotuła, Aplikacje mobilne nie tylko $w$ bibliotece, Warszawa 
lub informacją jednoznacznie wskazującą na jej mobilny charakter - na przykład „mobi”, „mobile”. Zwracają też uwagę różnice dotyczące zawartości strony mobilnej dedykowanej oraz desktopowej. Pierwsza jest jakby odchudzoną wersją drugiej. W przypadku witryn bibliotecznych, zawiera podstawowe informacje dotyczące funkcjonowania książnicy, często są to informacje dotyczące lokalizacji biblioteki, danych kontaktowych lub oferowanych usług ${ }^{5}$.

Inaczej sytuacja wygląda ze stronami responsywnymi i techniką ich projektowania (Web Responsive Design), którą śmiało możemy nazwać nową filozofią w tworzeniu internetowych witryn. Budowane są one w taki sposób, aby ich konstrukcja pozwalała na płynną adaptację do wielkości ekranu urządzenia, bez względu na to czy mamy do czynienia z monitorem, oknem smartfona, tabletu czy czytnika książek. Podstawowym założeniem jest automatyczne dostosowanie strony i jej prezentacji na wyświetlaczach różnej szerokości i wysokości. W ten sposób użytkownik nie musi martwić się o wygodę nawigacji i ręcznego przystosowania treści witryny do ekranu urządzenia, którym się posługuje. Tutaj także występuje konieczność powiększania czy pomniejszenia przeglądanego $\mathrm{w}$ danym momencie fragmentu konkretnej witryny, jednak w minimalnym stopniu. Dzięki technice Responsive Web Design strona jest wyświetlana szybko i poprawnie. Z punktu widzenia użytkownika stosującego urządzenia o różnej wielkości ekranu zmieniać się może jej wygląd, sposób nawigacji czy prezentowania zawartości. Jednak technicznie rzecz ujmując jest to ta sama strona, inaczej wyświetlona, ale $\mathrm{z}$ jednym adresem URL niezależnie od urządzenia, z którego korzystamy ${ }^{6}$.

\section{Google a responsywność stron WWW}

W kwietniu 2015 r. Google zaprezentowało nowy algorytm, który zasadniczo ma wpływ na wyniki wyszukiwania informacji za pomocą urządzeń przenośnych. Celem jest oczywiście dopasowanie treści do potrzeb użytkowników. Nie tylko jakość przekazu poszczególnych witryn WWW brana jest tutaj pod uwagę, ale także forma ich wyświetlania na ekranach różnych urządzeń. Ma to być według Google przekaz zoptymalizowany pod kątem tych urządzeń. Fakt ten oznacza, że strony internetowe, które nie są przyjazne urządzeniom mobilnym (zwłaszcza smartfonom) stopniowo tracą pozycję w wynikach rankingów wyszukiwania, co oczywiście ma decydujące odzwierciedlenie w liczbie

\footnotetext{
${ }^{4}$ Ibidem, s. 81 .

${ }^{5}$ Ibidem, s. 82.

${ }^{6}$ Zob. K. Kozieł, Strona mobilna czy responsywna? Oto jest dylemat!, http://enzo.pl /2013/06/26/strona-mobilna-czy-responsywna-oto-jest-dylemat, [dostęp: 12.04.2017].
} 
wyświetleń konkretnej strony na urządzeniach mobilnych i kwestii jej popularności wśród użytkowników. Krótko mówiąc, posiadanie strony responsywnej (ewentualnie mobilnej dedykowanej) jest od kwietnia 2015 r. nie tylko fanaberią czy ekstrawagancją, ale wymogiem dla wszystkich twórców stron WWW, którym zależy na ich częstym odwiedzaniu przez użytkowników za pomocą urządzeń $\mathrm{z}$ niewielkimi ekranami ${ }^{7}$. Mowa $\mathrm{w}$ tym miejscu także o wszelkiego rodzaju instytucjach edukacyjnych, naukowych czy kulturalnych, w tym oczywiście różnego typu bibliotekach.

\section{Metodologia badań}

Główną metodą badawczą wykorzystaną przez autora artykułu jest analiza stron internetowych osiemnastu polskich bibliotek uniwersyteckich z punktu widzenia responsywności i możliwości prawidłowego wyświetlania tych witryn na ekranach urządzeń przenośnych ${ }^{8}$. Postawiono następujące problemy badawcze:

1. Ile stron polskich bibliotek uniwersyteckich posiada responsywną stronę WWW?

2. Które strony bibliotek uniwersyteckich są najbardziej przyjazne urządzeniom mobilnym?

3. Jakie należy podjąć kroki, aby poprawić architekturę stron WWW i szybkość ich działania?

4. Czy, a jeśli tak, to które narzędzia wybrane do analizy bezbłędnie wskazują rzeczywiste przystosowanie strony do urządzeń mobilnych?

5. Czy poziom przystosowania danej strony do urządzeń mobilnych zawsze jest związany z szybkością jej działania?

6. Czy zdarzają się elementy nieresponsywne na responsywnych stronach? Jeśli tak, to w ilu przypadkach i jakie?

Autor badania postawił w związku z powyższym następujące cele:

- $\quad$ wyłonienie stron bibliotek najbardziej przyjaznych urządzeniom mobilnym;

- $\quad$ ustalenie zakresu czynności niezbędnych do poprawy architektury i szybkości działania stron WWW;

- $\quad$ potwierdzenie wiarygodności wykorzystanych do badania narzędzi testowych;

\footnotetext{
${ }^{7}$ E. Topolska, Strona responsywna to must have - Google przestało wspierać strony bez wersji mobilnych, http://www.mobiletrends.pl/strona-responsywna-to-must-have-google-przesta lo-wspierac-strony-bez-wersji-mobilnych, [dostęp: 12.04.2017].

${ }^{8}$ Wykaz stron zostal przygotowany na podstawie listy polskich uniwersytetów dostępnej na internetowej witrynie Ministerstwa Nauki i Szkolnictwa Wyższego.
} 
- $\quad$ ustalenie związku między poziomem przystosowania danej strony do urządzeń mobilnych a szybkością jej działania;

- $\quad$ ustalenie elementów, które nie są przystosowane do responsywności pomimo przyjaznych urządzeniom mobilnym stron, na których zostały zamieszczone.

Badania zostały przeprowadzone na początku kwietnia 2017 r. Badaniu porównawczemu poddano strony internetowe następujących bibliotek:

1. Biblioteka Uniwersytecka w Warszawie.

2. Biblioteka Uniwersytecka im. Jerzego Giedroycia w Białymstoku.

3. Biblioteka Uniwersytetu Gdańskiego.

4. Biblioteka Uniwersytecka w Poznaniu.

5. Biblioteka Jagiellońska Uniwersytetu Jagiellońskiego.

6. Biblioteka Uniwersytetu Łódzkiego.

7. Biblioteka Główna UMCS w Lublinie.

8. Biblioteka Uniwersytecka w Toruniu.

9. Biblioteka Główna Uniwersytetu Opolskiego.

10. Biblioteka Główna Uniwersytetu Szczecińskiego.

11. Biblioteka Uniwersytetu Śląskiego.

12. Biblioteka Uniwersytetu Rzeszowskiego.

13. Biblioteka Uniwersytecka Uniwersytetu Warmińsko-Mazurskiego w Olsztynie.

14. Biblioteka Uniwersytecka we Wrocławiu.

15. Biblioteka Główna Uniwersytetu Kardynała Stefana Wyszyńskiego w Warszawie.

16. Biblioteka Uniwersytetu Zielonogórskiego.

17. Biblioteka Uniwersytetu Kazimierza Wielkiego w Bydgoszczy.

18. Biblioteka Uniwersytecka w Kielcach.

\section{Testery responsywności stron WWW}

Sprawdzenie czy dana strona internetowa została wykonana zgodnie z techniką Responsive Web Design nie wymaga dzisiaj zaawansowanych narzędzi informatycznych umożliwiających testowanie wyglądu i układu witryny na ekranach urządzeń różnego typu (monitorów, smartfonów, tabletów). W sieci dostępne są liczne usługi, które w szybkim czasie sprawdzą i ocenią czy dana witryna WWW jest responsywna. Większość narzędzi pozwala także na symulację wyświetlania strony na urządzeniach z ekranami o różnej wielkości. Co więcej, symulacji mogą być poddane także wyświetlacze o różnej rozdzielczości występujące w najbardziej popularnych urządzeniach (także 
Porównanie dziesięciu narzędzi służących ocenie, jak dana strona WWW wygląda na ekranach różnych urządzeń

\begin{tabular}{|c|c|c|c|c|c|}
\hline $\begin{array}{l}\text { Nazwa narzędzia i adres jego strony } \\
\text { WWW }\end{array}$ & $\begin{array}{l}\text { Typ urządzenia } \\
\text { obslugiwanego } \\
\text { przez narzędzie }\end{array}$ & $\begin{array}{l}\text { Liczba dostęp- } \\
\text { nych rozdziel- } \\
\text { czości (oraz wiel- } \\
\text { kości ekranów) }\end{array}$ & $\begin{array}{l}\text { Pionowa/pozioma } \\
\text { orientacja ekranu } \\
\text { urządzenia }\end{array}$ & $\begin{array}{l}\text { Strona WWW/ } \\
\text { bookmarklet }{ }^{\mathrm{a}} / \\
\text { wtyczka do prze- } \\
\text { glądarki }\end{array}$ & $\begin{array}{l}\text { Obsługa strony } \\
\text { z poziomu sy- } \\
\text { mulacji okna } \\
\text { urządzenia }\end{array}$ \\
\hline $\begin{array}{l}\text { Am I resposive? } \\
\text { http://ami.responsivedesign.is/ }\end{array}$ & $\begin{array}{l}\text { Monitor, laptop, } \\
\text { tablet, smartfon }\end{array}$ & 4 & pionowa & $\begin{array}{l}\text { strona WWW i } \\
\text { bookmarklet }\end{array}$ & tak \\
\hline $\begin{array}{l}\text { Responsinator } \\
\text { http://www.responsinator.com }\end{array}$ & tablet, smartfon & 5 & pionowa i pozioma & $\begin{array}{l}\text { strona WWW i } \\
\text { bookmarklet }\end{array}$ & tak \\
\hline $\begin{array}{l}\text { Responsive Design Checker } \\
\text { http://responsivedesignchecker.com }\end{array}$ & $\begin{array}{l}\text { monitor, laptop, } \\
\text { tablet, smartfon }\end{array}$ & 10 & pionowa i pozioma & strona WWW & tak \\
\hline $\begin{array}{l}\text { Responsive Web Design Testing Tool } \\
\text { http://mattkersley.com/responsive/ }\end{array}$ & $\begin{array}{l}\text { tablet, } \\
\text { smartfon }\end{array}$ & $5^{b}$ & $\begin{array}{l}\text { pionowa i pozioma } \\
\text { (tablet) } \\
\text { pionowa (smartfon) }\end{array}$ & strona WWW & nie \\
\hline $\begin{array}{l}\text { Screenfly } \\
\text { http://quirktools.com/screenfly/ }\end{array}$ & $\begin{array}{l}\text { monitor, laptop, } \\
\text { tablet, smartfon, } \\
\text { telewizor }\end{array}$ & $\begin{array}{l}31 \text { (dodatkowo } \\
\text { możliwość zdefi- } \\
\text { niowania wła- } \\
\text { snych wartości) } \\
\end{array}$ & pozioma i pionowa & strona WWW & tak \\
\hline $\begin{array}{l}\text { Responsive Web Design Testing Tool } \\
\text { - Online }\end{array}$ & $\begin{array}{l}\text { tablet, smartfon, } \\
\text { czytnik książek }\end{array}$ & 5 & pionowa i pozioma & strona WWW & tak \\
\hline $\begin{array}{l}\text { ViewPort Resizer } \\
\text { http://lab.maltewassermann.com/viewport- } \\
\text { resizer/ }\end{array}$ & $\begin{array}{l}\text { laptop, tablet, } \\
\text { smartfon, telewi- } \\
\text { zor }\end{array}$ & $\begin{array}{l}8 \text { (dodatkowo } \\
\text { możliwość zdefi- } \\
\text { niowania wła- } \\
\text { snych wartości) } \\
\end{array}$ & pionowa i pozioma & $\begin{array}{l}\text { Bookmarklet, } \\
\text { wtyczka do prze- } \\
\text { glądarki Chrome }\end{array}$ & tak \\
\hline
\end{tabular}




\begin{tabular}{|c|c|c|c|c|c|}
\hline $\begin{array}{l}\text { Nazwa narzędzia i adres jego strony } \\
\text { WWW }\end{array}$ & $\begin{array}{l}\text { Typ urządzenia } \\
\text { obsługiwanego } \\
\text { przez narzędzie }\end{array}$ & $\begin{array}{l}\text { Liczba dostęp- } \\
\text { nych rozdziel- } \\
\text { czości (oraz wiel- } \\
\text { kości ekranów) }\end{array}$ & $\begin{array}{l}\text { Pionowa/pozioma } \\
\text { orientacja ekranu } \\
\text { urządzenia }\end{array}$ & $\begin{array}{l}\text { Strona WWW/ } \\
\text { bookmarklet/ } \\
\text { wtyczka do prze- } \\
\text { glądarki }\end{array}$ & $\begin{array}{l}\text { Obsługa strony } \\
\text { z poziomu sy- } \\
\text { mulacji okna } \\
\text { urządzenia }\end{array}$ \\
\hline $\begin{array}{l}\text { Responsive Design Bookmarklet } \\
\text { http://responsive.victorcoulon.fr/ }\end{array}$ & tablet, smartfon & 2 & pionowa i pozioma & bookmarklet & tak \\
\hline $\begin{array}{l}\text { Responsive Web Design Tester } \\
\mathrm{http}: / / \text { responsivewebdesigntester.com }\end{array}$ & tablet, smartfon & $\begin{array}{l}16 \text { (podział wiel- } \\
\text { kości ekranu we- } \\
\text { dług popularnych } \\
\text { na rynku urządzeń } \\
\text { z systemem iOS } \\
\text { oraz Android; } \\
\text { możliwość doda- } \\
\text { nia informacji o } \\
\text { innych urządze- } \\
\text { niach) }\end{array}$ & pionowa i pozioma & $\begin{array}{l}\text { wtyczka do prze- } \\
\text { glądarki (Opera, } \\
\text { Chrome, Firefox) }\end{array}$ & tak \\
\hline $\begin{array}{l}\text { Mobile/Responsive Web Design Tester } \\
\text { https://chrome.google.com/webstore/detail/ } \\
\text { mobileresponsive-web-desi// } \\
\text { elmekokodcohlommfikpmojheggnbelo }\end{array}$ & $\begin{array}{l}\text { tablet, smartfon, } \\
\text { fablet }\end{array}$ & $\begin{array}{l}16 \text { (możliwość } \\
\text { dodania informa- } \\
\text { cji o innych urzą- } \\
\text { dzeniach) }\end{array}$ & pionowa i pozioma & $\begin{array}{l}\text { wtyczka do prze- } \\
\text { glądarki } \\
\text { (Chrome) }\end{array}$ & tak \\
\hline
\end{tabular}

${ }^{a}$ Bookmarklet (skryptozakładka) to link udostępniony w formie przycisku, który w łatwy sposób można umieścić na pasku przeglądarki bez potrzeby instalowania dodatkowych wtyczek lub oprogramowania. Dzięki temu użytkownik nie musi za każdym razem, kiedy chce sprawdzić czy dana witryna jest responsywna, wchodzić na stronę z narzędziem umożliwiającym jej analizę z punktu widzenia wielkości ekranu urządzenia. Wystarczy, że kliknie w dostępny w pasku przeglądarki bookmarklet, który automatycznie umożliwi mu wywołanie narzędzia i dokonanie testu responsywności witryny, którą obecnie przegląda.

${ }^{\mathrm{b}} \mathrm{W}$ przypadku wskaźników rozdzielczości - na stronie internetowej usługi - dostępne są tylko informacje dotyczące szerokości ekranu. 
z punktu widzenia poszczególnych marek smartfonów, tabletów, fabletów ${ }^{9}$ ). W tab. 1 przedstawiono dziesięć darmowych narzędzi służących testowaniu witryn WWW, ale z punktu widzenia automatycznego dostosowania ich układu i treści do wielkości ekranu ${ }^{10}$. Pod uwagę wzięto przy tym możliwości sprawdzenia responsywności na podstawie kilku kryteriów wyświetlania strony: na ekranach urządzeń różnego typu i różnych marek (monitor komputera, laptop, tablet, smartfon, telewizor); liczby dostępnych rozdzielczości; pionowej i poziomej orientacji ekranu urządzenia; dostępności narzędzia jako usługi sieciowej, bookmarkletu lub wtyczki do przeglądarki; obsługi strony internetowej z poziomu okna z symulacją.

Wymienione w tab. 1 narzędzia umożliwiają wyświetlanie witryny WWW w różnej rozdzielczości i wielkości. Zdecydowanie najwięcej opcji prezentuje narzędzie Screenfly, które oprócz bogatej oferty wyboru urządzeń różnego typu i różnych marek, pozwala także na zdefiniowanie własnych wartości dotyczących wielkości ekranu. Co więcej, narzędzie to umożliwia też szybkie wygenerowanie linku do strony z prezentacją danej strony na wyświetlaczu o określonej wielkości. Jedyną dostrzeżoną wadą jest fakt, że strony internetowe, które nie zostały przygotowane jako witryny responsywne są prezentowane tutaj tylko w formie fragmentu, a nie pełnej treści danej strony WWW. Dodatkowo, użytkownik ma szansę nawigacji w obrębie jednego ekranu symulacji, bez możliwości przewijania w dół, ewentualnie w bok, strony (w przypadku stron nieprzystosowanych do wyświetlania na ekranach urządzeń mobilnych). Interfejs Screenfly (dla opcji powiązanej z jedną z dostępnych symulacji tabletu) został zaprezentowany na rysunku 1 .

Innym przydatnym narzędziem oceny zasobów stron WWW, z punktu widzenia zapoznawania się z nimi na ekranie urządzenia przenośnego, jest bez wątpienia ViewPort Resizer ułatwiający i przyśpieszający procedurę sprawdzania responsywności danej witryny. Również w tym przypadku bookmarklet, bo za jego pośrednictwem działa ta usługa, umożliwia analizę strony WWW na ekranach różnych typów urządzeń i różnych rozdzielczości. Użytkownik może także sam zdefiniować własne wartości dotyczące wielkości ekranu.

\footnotetext{
${ }^{9}$ Fablety to urządzenia mobilne wyposażone w ekrany o wielkości powyżej 5 cali, ale nie większej niż 7 cali. Jest to grupa urządzeń posiadających cechy smartfona i małego tabletu.

${ }^{10}$ Narzędzia zostały wybrane na podstawie ich popularności w wynikach wyszukiwania przeprowadzonych za pośrednictwem wyszukiwarki Google. W celu wyszukania narzędzi służących testowaniu, jak dana strona wygląda na ekranie różnych urządzeń, zadano pytanie „test responsive website” oraz „test responsie website plugin”.
} 


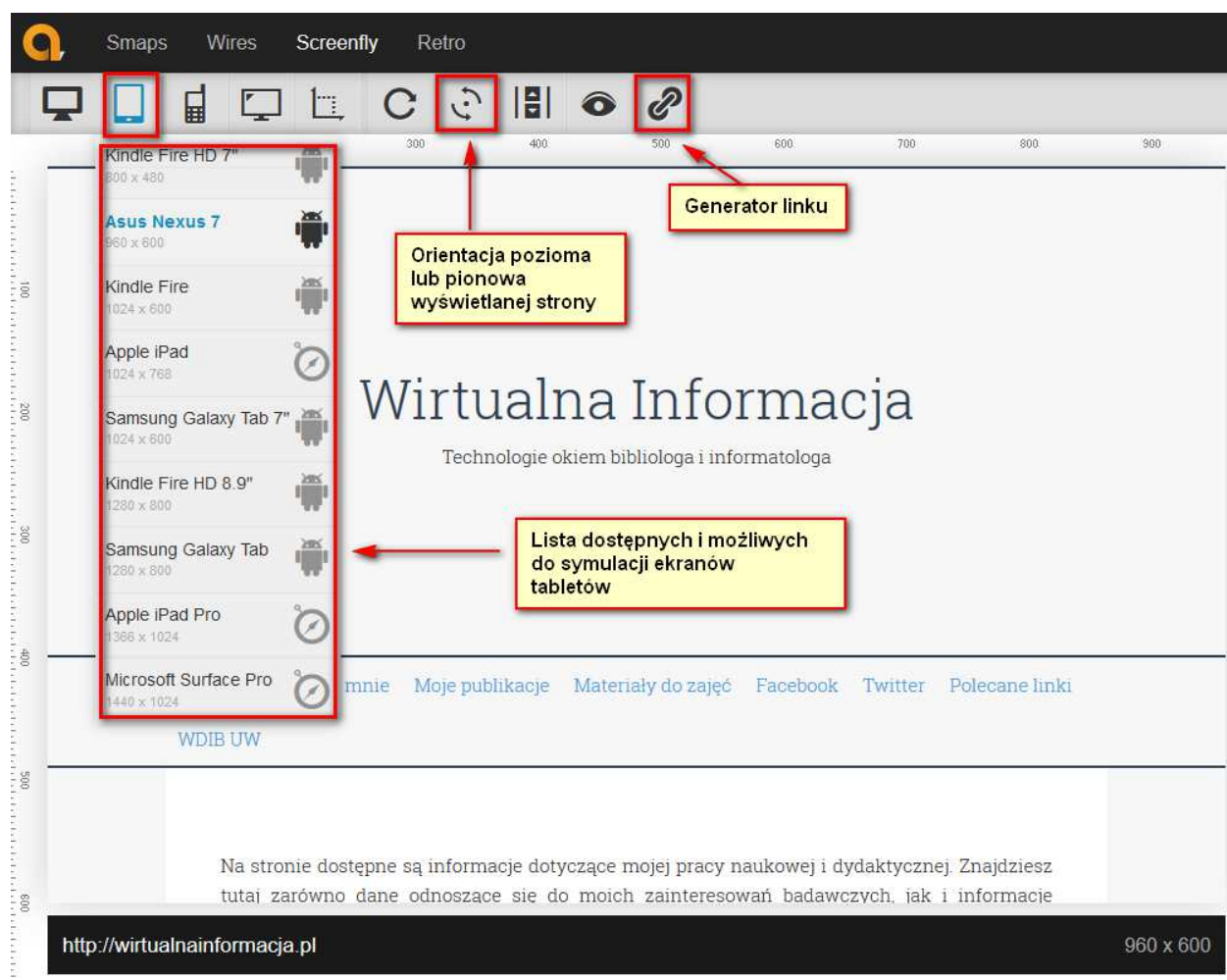

Rys. 1. Interfejs narzędzia Screenfly prezentujący analizę responsywności przykładowej strony wraz z informacjami o wybranych funkcjach.

Źródło: Opracowanie własne na podstawie zrzutu ekranu serwisu WWW http://quirk tools.com/screenfly/.

\section{Procedura badawcza}

Funkcja automatycznego dostosowania wyglądu i układu do okna urządzenia przenośnego osiemnastu internetowych stron bibliotek uniwersyteckich została zbadana za pomocą czterech narzędzi. W pierwszej fazie badania witryny poddano testom za pośrednictwem narzędzia Screenfly oraz ViewPort Resizer. Sprawdzano poprawność wyświetlania tych witryn za pomocą urządzenia Apple iPhone 5 (rozdzielczość 320x568 pikseli). Wyniki analizy zostały zaprezentowane w tab. 2. Informacje dostępne na szarym tle dotyczą stron internetowych, których wygląd jest automatycznie dostosowany do wielkości ekranów urządzeń mobilnych. Można więc założyć, że strony te są responsywne, choć nie zawsze pozbawione pewnych mankamentów, które odnoszą się do problemów prawidłowego wyświetlania wchodzących w skład ich treści elementów. 


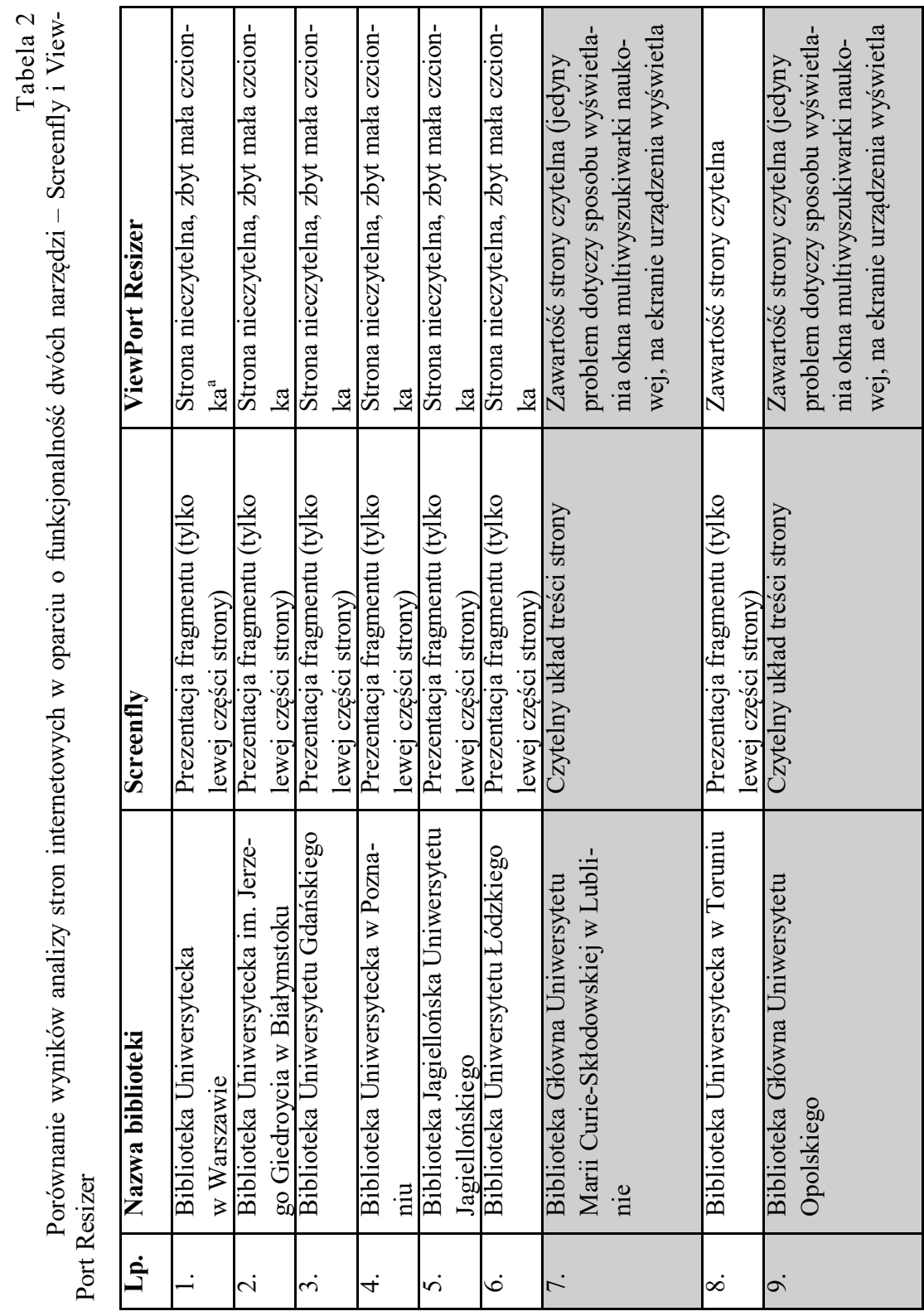




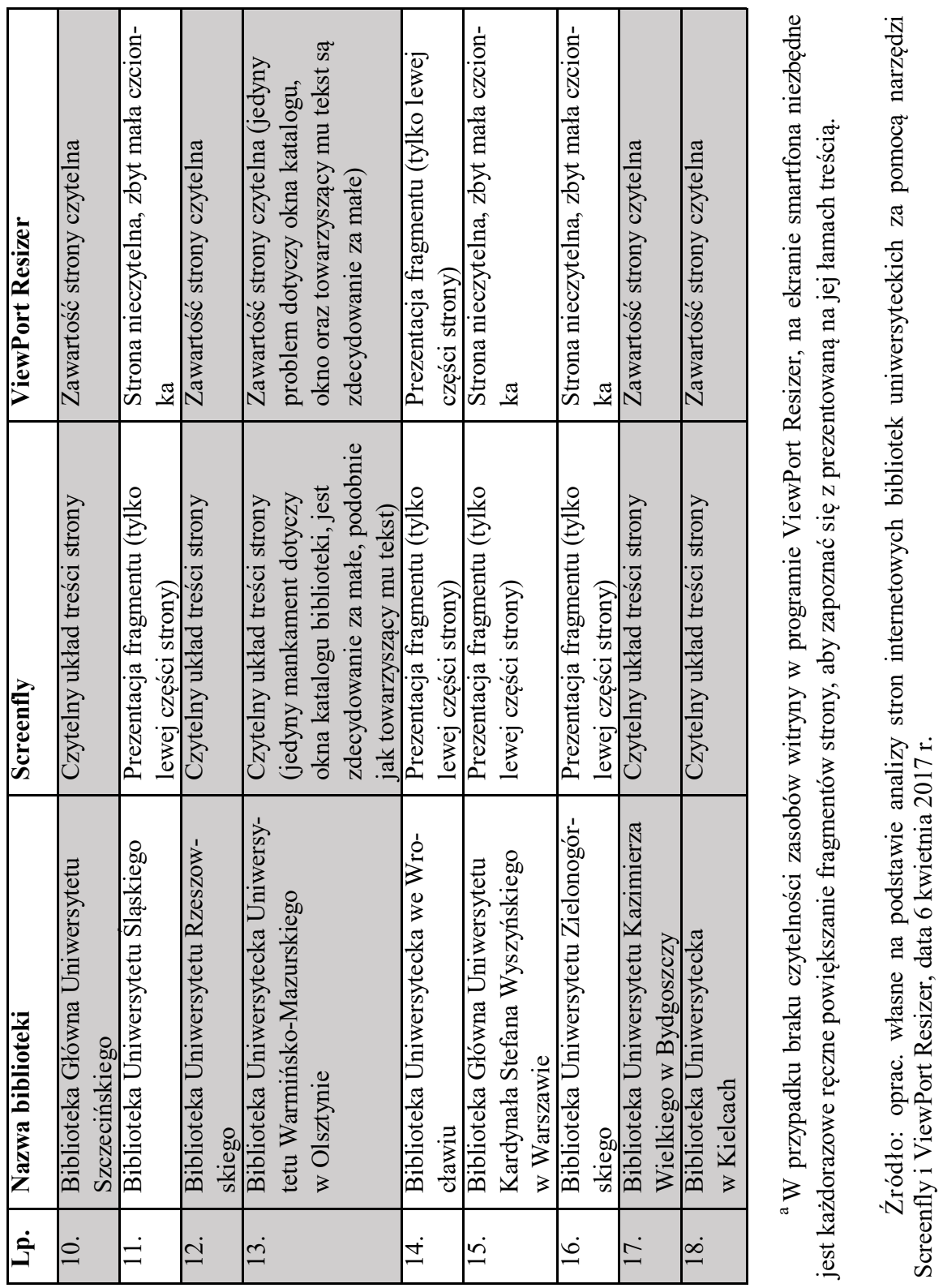


Na podstawie przeprowadzonego badania można stwierdzić, że w jedenastu przypadkach strony bibliotek nie są przystosowane do wyświetlania na niewielkich ekranach urządzeń mobilnych (szczególnie smartfonów). Czcionka tych stron jest zbyt mała, bez powiększenia tekstu jest on nieczytelny. W dwóch przypadkach stron, pomimo, że są one responsywne, okno multiwyszukiwarki naukowej nie jest w pełni zaprezentowane. Na ekranie urządzenia jest wyświetlona tylko część tego okna. W jednym przypadku, zarówno okno multiwyszukiwarki, jak i towarzyszące mu informacje tekstowe są zdecydowanie za małe. Niezbędne jest ich każdorazowe powiększanie. Reasumując, siedem z osiemnastu bibliotek posiada responsywne strony bibliotek, z czego tylko cztery można uznać za w pełni przyjazne urządzeniom mobilnym (strony instytucji: Biblioteka Główna Uniwersytetu Szczecińskiego, Biblioteka Uniwersytetu Rzeszowskiego, Biblioteka Uniwersytetu Kazimierza Wielkiego w Bydgoszczy i Biblioteka Uniwersytecka w Kielcach).

Aby zweryfikować pozyskane dane, w dalszej części badań posłużono się dwoma narzędziami Google - testem dotyczącym dostosowania stron WWW do telefonów komórkowych (smartfonów) ${ }^{11}$ oraz bardziej ogólnym Testem optymalizacji mobilnej ${ }^{12}$. Warto zauważyć, że to właśnie w drugim przypadku, po przeprowadzeniu automatycznej analizy, otrzymujemy jednoznaczną informację czy według Google dana strona jest przyjazna urzą-dzeniom mobilnym. Wyniki pierwszego testu dotyczą natomiast bardziej szczegółowych i bogatszych w użyteczne dla twórców danej strony porady (na przykład jak zmodyfikować stronę, aby była ona dostosowana do ekranów urządzeń mobilnych). Tego typu informacje zostały zawarte $\mathrm{w}$ tab. 4 . Wszystkie pochodzą $\mathrm{z}$ wniosków końcowych uzyskanych podczas przeprowadzania testu responsywności bibliotecznych witryn.

Warto dodać, że test dotyczący dostosowania stron WWW do telefonów komórkowych to efektywne narzędzie podstawowej diagnostyki witryn pod kątem ich szybkości i zgodności z ekranami urządzeń przenośnych. Wyniki procedury sprawdzania stron są podzielone na trzy części: dostosowanie do komórek, szybkość na komórkach oraz szybkość na komputerach. Każda $\mathrm{z}$ tych części testu jest scharakteryzowana $\mathrm{w}$ raporcie końcowym zgodnie z zastosowanym tutaj wskaźnikiem w skali od 1 do 100 (gdzie 100 oznacza dobre przygotowanie witryny). Do tych wyników dołączone są także informacje i porady, jak poprawić daną stronę, aby była ona bardziej przyjazna

${ }^{11}$ Zob. Sprawdź czy Twoja strona internetowa jest dostosowana do komórek, https:// testmysite.withgoogle.com/intl/pl-pl, [dostęp: 10.04.2017].

${ }_{12}$ Test optymalizacji mobilnej, https://search.google.com/search-console/mobile-friendly? $\mathrm{hl}=\mathrm{pl}$, [dostęp: 10.04.2017]. 
urządzeniom mobilnym (zwłaszcza smartfonom). Informacje te stanowią ważną część tab. 4. Dodatkowo, Google umożliwia otrzymanie przez użytkownika pełnego raportu testu na podany przez niego adres email.

Wyniki analizy zostały przedstawione w tab. 3 i 4 . W tab. 3 zaprezentowano informacje dotyczące analizy strony z punktu widzenia dostosowania jej zawartości, wyglądu, kompozycji do wielkości ekranów telefonów komórkowych; szybkości działania na tych urządzeniach, ale także - dla porównania - szybkości działania na komputerach. W tabeli znajdziemy także informację dotyczącą wyniku Testu optymalizacji mobilnej, a właściwie konkluzji czy dana strona jest przystosowana do ekranu smartfona i spełnia kryteria strony responsywnej.

\section{Wnioski}

1. Z danych pozyskanych podczas badań wynika, że najbardziej przyjazne urządzeniom mobilnym są internetowe strony Biblioteki Uniwersytetu Kazimierza Wielkiego w Bydgoszczy, Biblioteki Uniwersytetu Rzeszowskiego oraz Biblioteki Uniwersyteckiej w Toruniu. Dowodem takiego stanu rzeczy są zwłaszcza wyniki testu Google dotyczącego dostosowania stron WWW do wielkości ekranów telefonów komórkowych, ale także kwestie odnoszące się do szybkości działania tych witryn na telefonach komórkowych i komputerach.

2. Przeprowadzenie testu responsywności za pośrednictwem narzędzia Google umożliwiło także uzyskanie praktycznych informacji i porad ułatwiających techniczną modyfikację danej strony w celu jej przystosowania do ekranów urządzeń mobilnych. W przypadku stron internetowych, które nie spełniają wymagań responsywności, pojawiają się rady odnoszące się między innymi do konieczności używania czytelnych rozmiarów czcionek, wykorzystania odpowiedniego rozmiaru elementów dotykowych czy optymalizacji obrazów. Natomiast w wynikach analiz funkcjonalności responsywnych stron internetowych znajdziemy mniej lub bardziej liczne wskazówki, które mogą dodatkowo pomóc usprawnić działanie tych witryn. Dostępne są w tym przypadku między innymi pomocne informacje dotyczące problemu bezstratnej kompresji danych przesyłanych z serwera do komputera użytkownika ${ }^{13}$, optymalizacji obrazów czy wykorzystania pamięci podręcznej przeglądarki. Z technicznego punktu widzenia,

${ }^{13}$ Zob. PageSpeed Insights. Wtacz kompresje, https://developers.google.com/speed/docs/ insights/EnableCompression, [dostęp 21.08.2017]. 
w przypadku każdej z analizowanych stron internetowych można dokonać pewnych poprawek, które pomogą zoptymalizować witrynę i jej obsługę, jak również szybkość jej działania za pośrednictwem urządzeń przenośnych (zob. tab. 4).

3. Przeprowadzenie dwóch testów przygotowanych przez firmę Google wykazało, że dziesięć stron bibliotek uniwersyteckich z osiemnastu przebadanych nie jest przystosowanych do małych ekranów urządzeń przenośnych. Ich zawartość, bez ręcznego powiększania, jest raczej nieczytelna. W przypadku Biblioteki Uniwersyteckiej w Toruniu wyniki dwóch wcześniej przeprowadzonych testów (za pomocą narzędzi Screenfly i ViewPort Resizer) wykazały nieprzystosowanie tej witryny do urządzeń mobilnych. Jednak narzędzia Google wykorzystane w dalszej części badania jednoznacznie oceniają tę stronę jako przyjazną dla smartfonów (96 punktów w skali od 1 do 100). Fakt ten potwierdził zresztą dodatkowy test przeprowadzony za pośrednictwem smartfona (rozdzielczość 1280x720), który wykazał, że zawartość strony wyświetla się poprawnie i nie ma potrzeby wykonywania dodatkowych czynności umożliwiających na przykład przeczytanie dostępnego na łamach tej witryny tekstu ${ }^{14}$. Dodatkowo, w przypadku jednej witryny internetowej (Biblioteki Głównej Uniwersytetu Szczecińskiego) pojawił się ewidentny błąd dotyczący wyniku testu przeprowadzonego za pośrednictwem narzędzia Google umożliwiającego analizę stopnia przystosowania stron WWW do urządzeń mobilnych; wynik tego testu był negatywny, pomimo faktu, że bez wątpienia strona jest responsywna i spełnia warunki optymalizacji z punktu widzenia urządzeń mobilnych; zresztą resposywność tej strony została potwierdzona w drugim teście Google oraz w wynikach analiz przeprowadzonych za pośrednictwem dwóch innych dodatkowych narzędzi. Widać więc wyraźnie, że nie we wszystkich przypadkach stron internetowych wykorzystane podczas badania narzędzia prowadzą do jednakowych wniosków i nie zawsze funkcjonalność czy wiarygodność tych mechanizmów jest stuprocentowo pewna. Zdecydowanie pewniejszym narzędziem w trakcie analiz są testy przygotowane przez firmę Google. Choć w przypadku przeprowadzenia jednego z nich także pojawił się błąd.

4. Na łamach trzech stron (Biblioteki Głównej UMCS w Lublinie, Biblioteki Głównej Uniwersytetu Opolskiego oraz Biblioteki Uniwersyteckiej

\footnotetext{
${ }^{14}$ Za ciekawostkę można uznać fakt, że w sierpniu 2017 r. strona Biblioteki Uniwersyteckiej w Toruniu pozytywnie przeszła test wykonany za pomocą narzędzia ViewPort Resizer. $\mathrm{W}$ przypadku drugiego z wcześniej wykorzystanych testerów responsywności nie było możliwości jego zastosowania w kontekście sprawdzenia tej witryny pod kątem jej dostosowania do wielkości wyświetlaczy telefonów komórkowych (smartfonów).
} 
Uniwersytetu Warmińsko-Mazurskiego w Olsztynie), które zostały jednoznacznie ocenione jako responsywne i przystosowane do wielkości ekranów urządzeń mobilnych występuje element w postaci okna katalogu lub multiwyszukiwarki naukowej nieprzystosowany do wyglądu i kompozycji tych witryn (na przykład strona BG UMCS zawiera wyszukiwarkę naukową Primo, ale użytkownik, aby móc z niej w pełni skorzystać musi ręcznie zmniejszyć okno wyświetlania strony, ewentualnie przesunąć ekran w bok).

5. Bardzo dobra ocena poziomu przystosowania danej strony do wielkości ekranów małych urządzeń przenośnych nie musi oznaczać bardzo dobrej oceny szybkości działania witryny za pomocą urządzeń mobilnych czy komputerów. Na przykład strona Biblioteki Głównej Uniwersytetu Opolskiego w pierwszym przypadku została oceniona jako dobra - 99 na 100 punktów, a w dwóch kolejnych testach oceniono ją jako słabą - 30 i 31 punktów. Podobnie zresztą sytuacja wygląda w przypadku strony Biblioteki Głównej Uniwersytetu Szczecińskiego, której poziom przystosowania do ekranów telefonów został oceniony na 99, a szybkość działania na telefonach i komputerach kolejno na 38 i 39 punktów czy Biblioteki Uniwersyteckiej w Kielcach (99, 44 i 47 punktów). Widać więc wyraźnie, że nie zawsze poziom przystosowania danej strony do urządzeń mobilnych jest bezpośrednio związany z szybkością jej działania. Warto zaznaczyć, że najlepiej w tym teście wypadła witryna Biblioteki Uniwersytetu Rzeszowskiego (95, 74 i 89 punktów). 


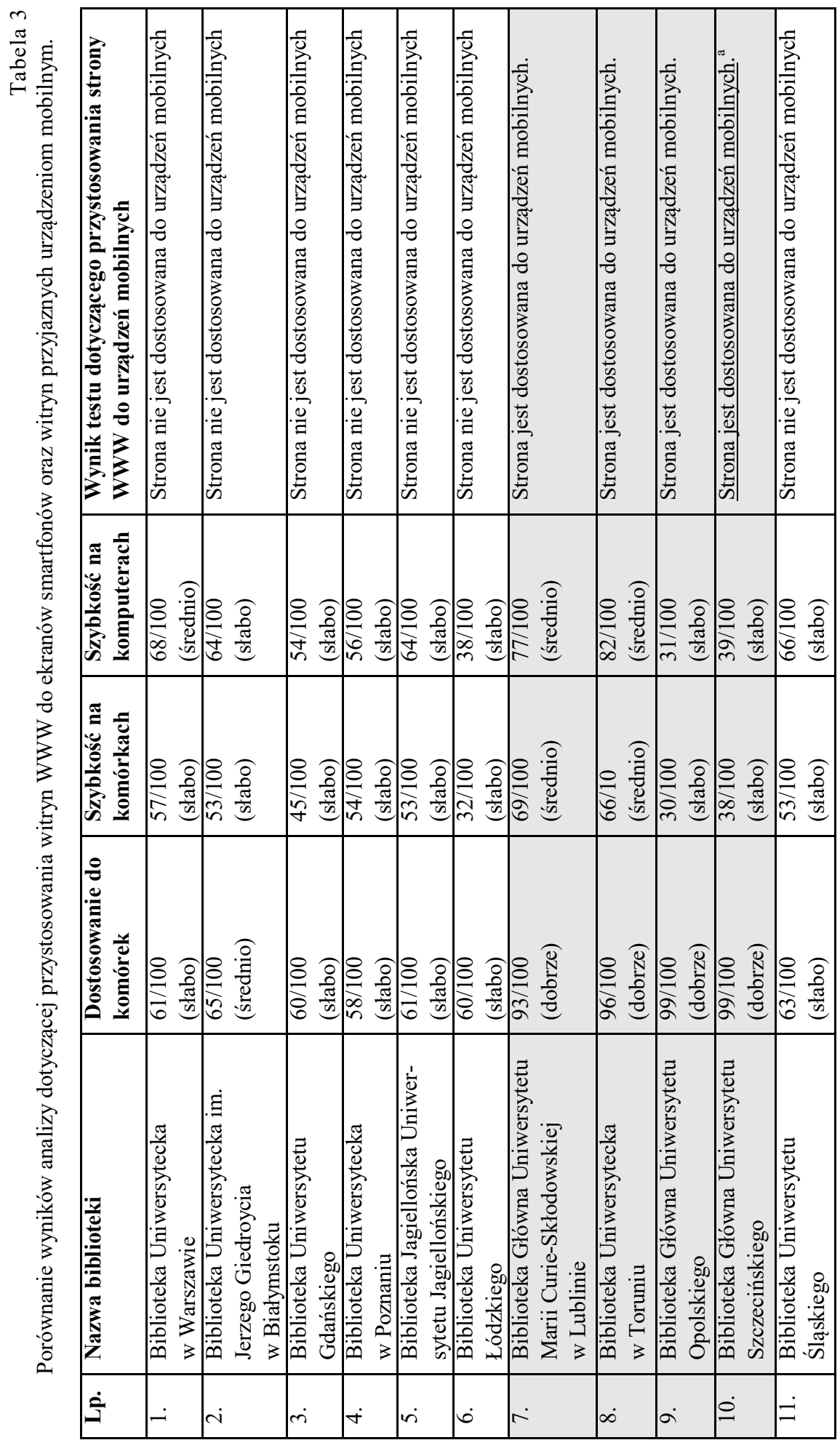




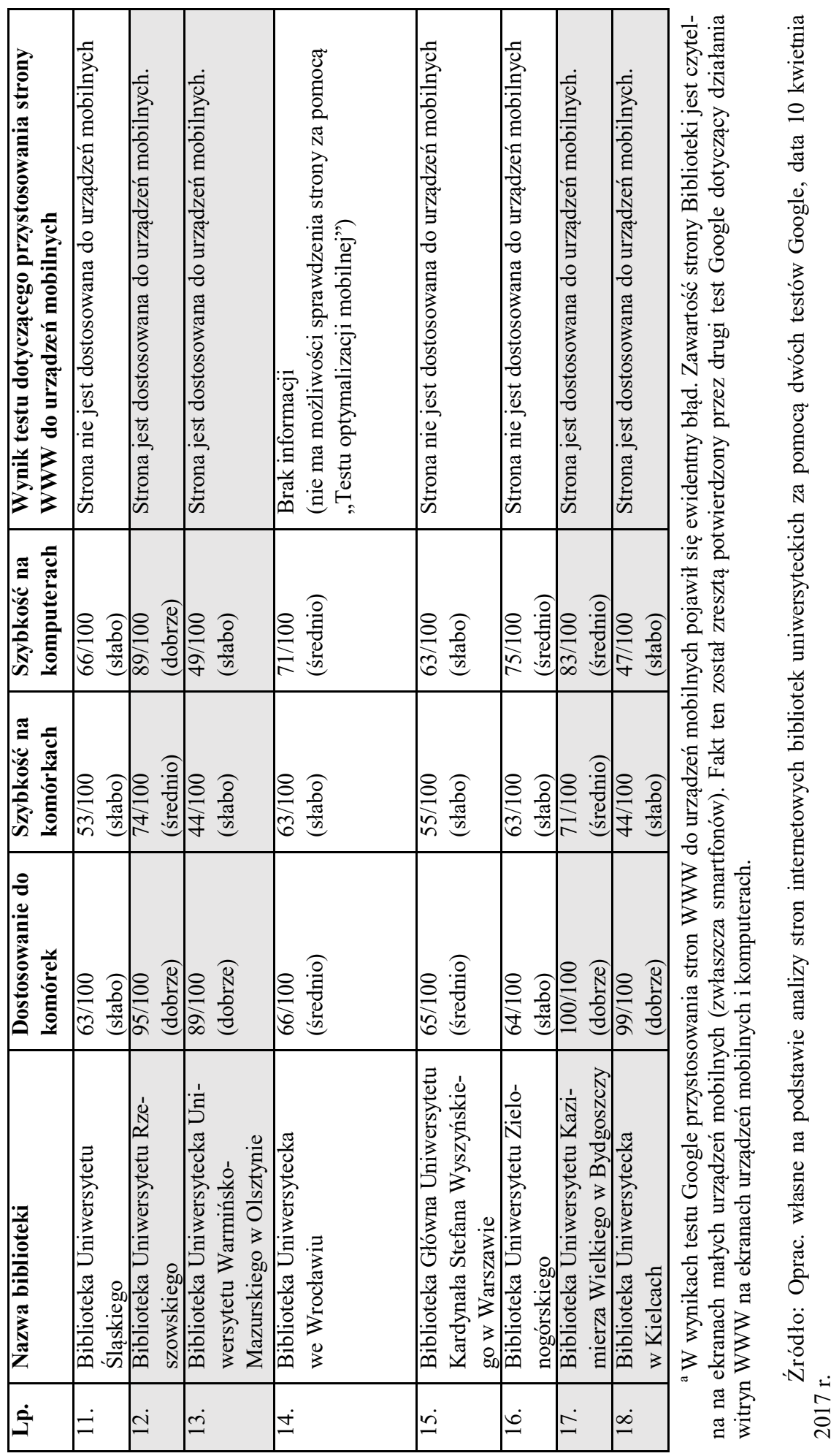


Tabela 4

Uwagi wynikające $\mathrm{z}$ analiz responsywności internetowych stron bibliotek uniwersyteckich przeprowadzonych za pomocą testu Google (przystosowanie witryn do ekranów smartfonów).

\begin{tabular}{|c|c|c|}
\hline Lp. & $\begin{array}{l}\text { Nazwa i adres internetowy } \\
\text { biblioteki }\end{array}$ & $\begin{array}{l}\text { Wytyczne narzędzia testującego, które } \\
\text { mogą pomóc usprawnić dzialanie strony }\end{array}$ \\
\hline 1. & $\begin{array}{l}\text { Biblioteka Uniwersytecka } \\
\text { w Warszawie } \\
\text { (http://www.buw.uw.edu.pl/) }\end{array}$ & $\begin{array}{l}\text { Trzeba poprawić: } \\
\text { używaj czytelnych rozmiarów czcionek } \\
\text { dobierz odpowiedni rozmiar elementów } \\
\text { dotykowych } \\
\text { konfiguracja okna roboczego } \\
\text { wyeliminuj blokujący renderowanie kod } \\
\text { JavaScript i CSS z części strony wi- } \\
\text { docznej na ekranie } \\
\text { wykorzystaj pamięć podręczną przeglądarki } \\
\text { zoptymalizuj obrazy } \\
\text { włącz kompresję } \\
\text { Warto poprawić: } \\
\text { skróć czas odpowiedzi serwera } \\
\text { zmniejsz CSS }\end{array}$ \\
\hline 2. & $\begin{array}{l}\text { Biblioteka Uniwersytecka im. Jerzego } \\
\text { Giedroycia w Białymstoku } \\
\text { (http://bg.uwb.edu.pl/) }\end{array}$ & $\begin{array}{l}\text { Trzeba poprawić: } \\
\text { używaj czytelnych rozmiarów czcionek } \\
\text { dobierz odpowiedni rozmiar elementów } \\
\text { dotykowych } \\
\text { konfiguracja okna roboczego } \\
\text { wykorzystaj pamięć podręczną przeglądarki } \\
\text { wyeliminuj blokujący renderowanie kod } \\
\text { JavaScript i CSS z części strony wi- } \\
\text { docznej na ekranie } \\
\text { zoptymalizuj obrazy } \\
\text { Warto poprawić: } \\
\text { dopasowanie rozmiaru do okna roboczego } \\
\text { włącz kompresję } \\
\text { zmniejsz JavaScript }\end{array}$ \\
\hline 3. & $\begin{array}{l}\text { Biblioteka Uniwersytetu Gdańskiego } \\
\text { (http://www.bg.ug.edu.pl/) }\end{array}$ & $\begin{array}{l}\text { Trzeba poprawić: } \\
\text { używaj czytelnych rozmiarów czcionek } \\
\text { dobierz odpowiedni rozmiar elementów } \\
\text { dotykowych } \\
\text { konfiguracja okna roboczego } \\
\text { wyeliminuj blokujący renderowanie kod } \\
\text { JavaScript i CSS z części strony wi- } \\
\text { docznej na ekranie } \\
\text { wykorzystaj pamięć podręczną przeglądarki } \\
\text { zoptymalizuj obrazy } \\
\text { włącz kompresję } \\
\text { Warto poprawić: } \\
\text { zmniejsz CSS } \\
\text { zmniejsz HTML } \\
\text { zmniejsz JavaScript } \\
\end{array}$ \\
\hline
\end{tabular}

${ }^{a}$ Szczegółowe informacje dotyczące poszczególnych uwag i wskazówek dostępne są w automatycznie przygotowanych przez narzędzie Google raportach dotyczących analizy testowanych witryn bibliotecznych. 


\begin{tabular}{|c|c|c|}
\hline Lp. & Nazwa i adres internetowy biblioteki & $\begin{array}{l}\text { Wytyczne narzędzia testującego, które } \\
\text { mogą pomóc usprawnić działanie stro- } \\
\text { ny }\end{array}$ \\
\hline 4. & $\begin{array}{l}\text { Biblioteka Uniwersytecka } \\
\text { w Poznaniu } \\
\text { (http://lib.amu.edu.pl/) }\end{array}$ & $\begin{array}{l}\text { Trzeba poprawić: } \\
\text { używaj czytelnych rozmiarów czcionek } \\
\text { dobierz odpowiedni rozmiar elementów } \\
\text { dotykowych } \\
\text { konfiguracja okna roboczego } \\
\text { wykorzystaj pamięć podręczną przeglą- } \\
\text { darki } \\
\text { wyeliminuj blokujący renderowanie kod } \\
\text { JavaScript i CSS z części strony } \\
\text { widocznej na ekranie } \\
\text { zoptymalizuj obrazy } \\
\text { Warto poprawić: } \\
\text { dopasowanie rozmiaru do okna robocze- } \\
\text { go } \\
\text { włącz kompresję } \\
\text { zmniejsz JavaScript } \\
\text { zmniejsz CSS } \\
\text { zmniejsz HTML }\end{array}$ \\
\hline 5. & $\begin{array}{l}\text { Biblioteka Jagiellońska Uniwersytetu } \\
\text { Jagiellońskiego (http://www.bj.uj.edu.pl/) }\end{array}$ & $\begin{array}{l}\text { Trzeba poprawić: } \\
\text { używaj czytelnych rozmiarów czcionek } \\
\text { dobierz odpowiedni rozmiar elementów } \\
\text { dotykowych } \\
\text { konfiguracja okna roboczego } \\
\text { wyeliminuj blokujący renderowanie kod } \\
\text { JavaScript i CSS z części strony } \\
\text { widocznej na ekranie } \\
\text { zoptymalizuj obrazy } \\
\text { zmniejsz JavaScript } \\
\text { Warto poprawić: } \\
\text { dopasowanie rozmiaru do okna robocze- } \\
\text { go } \\
\text { wykorzystaj pamięć podręczną przeglą- } \\
\text { darki } \\
\text { skróć czas odpowiedzi serwera } \\
\text { zmniejsz CSS } \\
\text { zmniejsz HTML }\end{array}$ \\
\hline 6. & $\begin{array}{l}\text { Biblioteka Uniwersytetu Łódzkiego } \\
\text { (http://www.lib.uni.lodz.pl/) }\end{array}$ & $\begin{array}{l}\text { Trzeba poprawić: } \\
\text { używaj czytelnych rozmiarów czcionek } \\
\text { dobierz odpowiedni rozmiar elementów } \\
\text { dotykowych } \\
\text { konfiguracja okna roboczego } \\
\text { włącz kompresję } \\
\text { wyeliminuj blokujący renderowanie kod } \\
\text { JavaScript i CSS z części strony } \\
\text { widocznej na ekranie } \\
\text { wykorzystaj pamięć podręczną przeglą- } \\
\text { darki } \\
\text { zoptymalizuj obrazy } \\
\text { zmniejsz JavaScript } \\
\text { Warto poprawić: } \\
\text { zmniejsz CSS } \\
\text { zmniejsz HTML }\end{array}$ \\
\hline
\end{tabular}


Tabela 4 c.d.

\begin{tabular}{|c|c|c|}
\hline Lp. & Nazwa i adres internetowy biblioteki & $\begin{array}{l}\text { Wytyczne narzędzia testującego, które } \\
\text { mogą pomóc usprawnić dzialanie strony }\end{array}$ \\
\hline 7. & $\begin{array}{l}\text { Biblioteka Główna Uniwersytetu Marii } \\
\text { Curie-Skłodowskiej w Lublinie } \\
\text { (http://www.umcs.pl/pl/biblioteka.htm) }\end{array}$ & $\begin{array}{l}\text { Trzeba poprawić: } \\
\text { włącz kompresję } \\
\text { Warto poprawić: } \\
\text { dobierz odpowiedni rozmiar elementów } \\
\text { dotykowych } \\
\text { dopasowanie rozmiaru do okna roboczego } \\
\text { wyeliminuj blokujący renderowanie kod } \\
\text { JavaScript i CSS z części strony wi- } \\
\text { docznej na ekranie } \\
\text { nadaj priorytet widocznej treści } \\
\text { wykorzystaj pamięć podręczną przeglądar- } \\
\text { ki } \\
\text { zoptymalizuj obrazy } \\
\text { skróć czas odpowiedzi serwera } \\
\text { zmniejsz HTML }\end{array}$ \\
\hline 8. & $\begin{array}{l}\text { Biblioteka Uniwersytecka w Toruniu } \\
\text { (https://www.bu.umk.pl/) }\end{array}$ & $\begin{array}{l}\text { Trzeba poprawić: } \\
\text { unikaj przekierowań stron docelowych } \\
\text { wyeliminuj blokujący renderowanie kod } \\
\quad \text { JavaScript i CSS z części strony wi- } \\
\quad \text { docznej na ekranie } \\
\text { Warto poprawić: } \\
\text { dopasowanie rozmiaru do okna roboczego } \\
\text { zoptymalizuj obrazy }\end{array}$ \\
\hline 9. & $\begin{array}{l}\text { Biblioteka Główna Uniwersytetu Opol- } \\
\text { skiego } \\
\text { (http://bg.uni.opole.pl/) }\end{array}$ & $\begin{array}{l}\text { Trzeba poprawić: } \\
\text { włącz kompresję } \\
\text { zoptymalizuj obrazy } \\
\text { wykorzystaj pamięć podręczną przeglądar- } \\
\text { ki } \\
\text { zmniejsz JavaScript } \\
\text { skróć czas odpowiedzi serwera } \\
\text { Warto poprawić: } \\
\text { dobierz odpowiedni rozmiar elementów } \\
\text { dotykowych } \\
\text { wyeliminuj blokujący renderowanie kod } \\
\text { JavaScript i CSS z części strony wi- } \\
\text { docznej na ekranie } \\
\text { zmniejsz HTML } \\
\text { zmniejsz CSS }\end{array}$ \\
\hline 10. & $\begin{array}{l}\text { Biblioteka Główna Uniwersytetu } \\
\text { Szczecińskiego } \\
\text { (http://bg.szczecin.pl/) }\end{array}$ & $\begin{array}{l}\text { Trzeba poprawić: } \\
\text { zoptymalizuj obrazy } \\
\text { włącz kompresję } \\
\text { wykorzystaj pamięć podręczną prze- } \\
\text { glądarki } \\
\text { Warto poprawić: } \\
\text { wyeliminuj blokujący renderowanie kod } \\
\text { JavaScript i CSS z części strony wi- } \\
\text { docznej na ekranie } \\
\text { zmniejsz HTML } \\
\text { zmniejsz CSS }\end{array}$ \\
\hline
\end{tabular}




\begin{tabular}{|c|c|c|}
\hline Lp. & Nazwa i adres internetowy biblioteki & $\begin{array}{l}\text { Wytyczne narzędzia testującego, które } \\
\text { mogą pomóc usprawnić dzialanie strony }\end{array}$ \\
\hline 11. & $\begin{array}{l}\text { Biblioteka Uniwersytetu Sląskiego } \\
\text { (http://www.bg.us.edu.pl/) }\end{array}$ & $\begin{array}{l}\text { Trzeba poprawić: } \\
\text { używaj czytelnych rozmiarów czcionek } \\
\text { dobierz odpowiedni rozmiar elementów } \\
\text { dotykowych } \\
\text { konfiguracja okna roboczego } \\
\text { wyeliminuj blokujący renderowanie kod } \\
\text { JavaScript i CSS z części strony wi- } \\
\text { docznej na ekranie } \\
\text { wykorzystaj pamięć podręczną przeglądarki } \\
\text { skróć czas odpowiedzi serwera } \\
\text { włącz kompresję } \\
\text { Warto poprawić: } \\
\text { zoptymalizuj obrazy } \\
\text { zmniejsz CSS } \\
\text { zmniejsz JavaScript } \\
\text { zmniejsz HTML } \\
\end{array}$ \\
\hline 12. & $\begin{array}{l}\text { Biblioteka Uniwersytetu } \\
\text { Rzeszowskiego } \\
\text { (http://bur.ur.edu.pl/) }\end{array}$ & $\begin{array}{l}\text { Trzeba poprawić: } \\
\text { wyeliminuj blokujący renderowanie kod } \\
\text { JavaScript i CSS z części strony wi- } \\
\text { docznej na ekranie } \\
\text { Warto poprawić: } \\
\text { dobierz odpowiedni rozmiar elementów } \\
\text { dotykowych } \\
\text { wykorzystaj pamięć podręczną przeglądarki } \\
\text { zmniejsz JavaScript } \\
\text { zoptymalizuj obrazy }\end{array}$ \\
\hline 13. & $\begin{array}{l}\text { Biblioteka Uniwersytecka Uniwersyte- } \\
\text { tu Warmińsko-Mazurskiego } \\
\text { w Olsztynie } \\
\text { (http://bu.uwm.edu.pl/) }\end{array}$ & $\begin{array}{l}\text { Trzeba poprawić: } \\
\text { zoptymalizuj obrazy } \\
\text { wyeliminuj blokujący renderowanie kod } \\
\text { JavaScript i CSS z części strony wi- } \\
\text { docznej na ekranie } \\
\text { włącz kompresję } \\
\text { Warto poprawić: } \\
\text { dobierz odpowiedni rozmiar elementów } \\
\text { dotykowych } \\
\text { dopasowanie rozmiaru do okna roboczego } \\
\text { nadaj priorytet widocznej treści } \\
\text { zmniejsz JavaScript } \\
\text { skróć czas odpowiedzi serwera } \\
\text { wykorzystaj pamięć podręczną przeglądarki } \\
\text { zmniejsz CSS }\end{array}$ \\
\hline 14. & $\begin{array}{l}\text { Biblioteka Uniwersytecka } \\
\text { we Wrocławiu } \\
\text { (http://www.bu.uni.wroc.pl/) }\end{array}$ & $\begin{array}{l}\text { Trzeba poprawić: } \\
\text { dopasowanie rozmiaru do okna roboczego } \\
\text { wyeliminuj blokujący renderowanie kod } \\
\text { JavaScript i CSS z części strony wi- } \\
\text { docznej na ekranie } \\
\text { włącz kompresję } \\
\text { Warto poprawić: } \\
\text { dobierz odpowiedni rozmiar elementów } \\
\text { dotykowych } \\
\text { zoptymalizuj obrazy } \\
\text { zmniejsz JavaScript } \\
\text { zmniejsz CSS }\end{array}$ \\
\hline
\end{tabular}


Tabela 4 c.d.

\begin{tabular}{|c|c|c|}
\hline Lp. & Nazwa i adres internetowy biblioteki & $\begin{array}{l}\text { Wytyczne narzędzia testującego, które } \\
\text { mogą pomóc usprawnić dzialanie strony }\end{array}$ \\
\hline 15. & $\begin{array}{l}\text { Biblioteka Główna Uniwersytetu Kar- } \\
\text { dynała Stefana Wyszyńskiego } \\
\text { w Warszawie } \\
\text { (http://www.biblioteka.uksw.edu.pl/) }\end{array}$ & $\begin{array}{l}\text { Trzeba poprawić: } \\
\text { używaj czytelnych rozmiarów czcionek } \\
\text { konfiguracja okna roboczego } \\
\text { wykorzystaj pamięć podręczną przeglądarki } \\
\text { zoptymalizuj obrazy } \\
\text { wyeliminuj blokujący renderowanie kod } \\
\text { JavaScript i CSS z części strony wi- } \\
\text { docznej na ekranie } \\
\text { skróć czas odpowiedzi serwera } \\
\text { Warto poprawić: } \\
\text { dobierz odpowiedni rozmiar elementów } \\
\text { dotykowych } \\
\text { zmniejsz JavaScript } \\
\text { zmniejsz CSS }\end{array}$ \\
\hline 16. & $\begin{array}{l}\text { Biblioteka Uniwersytetu Zielonogór- } \\
\text { skiego } \\
\text { (http://www.bu.uz.zgora.pl/index.php/ } \\
\text { pl/) }\end{array}$ & $\begin{array}{l}\text { Trzeba poprawić: } \\
\text { używaj czytelnych rozmiarów czcionek } \\
\text { konfiguracja okna roboczego } \\
\text { wyeliminuj blokujący renderowanie kod } \\
\text { JavaScript i CSS z części strony wi- } \\
\text { docznej na ekranie } \\
\text { zoptymalizuj obrazy } \\
\text { skróć czas odpowiedzi serwera } \\
\text { Warto poprawić: } \\
\text { dobierz odpowiedni rozmiar elementów } \\
\text { dotykowych } \\
\text { wykorzystaj pamięć podręczną przeglądarki } \\
\text { zmniejsz CSS } \\
\text { zmniejsz JavaScript } \\
\text { włącz kompresję } \\
\text { zmniejsz HTML }\end{array}$ \\
\hline 17. & $\begin{array}{l}\text { Biblioteka Uniwersytetu Kazimierza } \\
\text { Wielkiego w Bydgoszczy } \\
\text { (http://biblioteka.ukw.edu.pl/) }\end{array}$ & $\begin{array}{l}\text { Trzeba poprawić: } \\
\text { wyeliminuj blokujący renderowanie kod } \\
\text { JavaScript i CSS z części strony wi- } \\
\text { docznej na ekranie } \\
\text { wykorzystaj pamięć podręczną przeglądarki } \\
\text { Warto poprawić: } \\
\text { zoptymalizuj obrazy }\end{array}$ \\
\hline 18. & $\begin{array}{l}\text { Biblioteka Uniwersytecka w Kielcach } \\
\text { (http://www.buk.ujk.edu.pl/) }\end{array}$ & $\begin{array}{l}\text { Trzeba poprawić: } \\
\text { zoptymalizuj obrazy } \\
\text { wykorzystaj pamięć podręczną przeglądarki } \\
\text { Warto poprawić: } \\
\text { wyeliminuj blokujący renderowanie kod } \\
\text { JavaScript i CSS z części strony wi- } \\
\text { docznej na ekranie } \\
\text { zmniejsz CSS } \\
\text { zmniejsz JavaScript } \\
\text { zmniejsz HTML }\end{array}$ \\
\hline
\end{tabular}

Źródło: Wytyczne narzędzia testującego Google, które mogą pomóc usprawnić działanie strony, data 10 kwietnia $2017 \mathrm{r}$. 
Podsumowując, aktualnie w Stanach Zjednoczonych Ameryki Północnej 94\% użytkowników smartfonów poszukuje lokalnych informacji za pomocą telefonu komórkowego, a 77\% ich poszukiwań dokonywanych za pośrednictwem urządzeń mobilnych ma miejsce w domu lub w pracy, czyli tam, gdzie teoretycznie mogliby skorzystać z tradycyjnych komputerów ${ }^{15}$. Biblioteki (niezależnie od ich typu) powinny wziąć pod uwagę zmiany dokonujące się w kontekście wykorzystania przez użytkowników różnych urządzeń (nie tylko desktopowych) w celu dotarcia do potrzebnych im treści. Od kilkunastu lat jesteśmy świadkami dynamicznej ewolucji w tworzeniu, gromadzeniu, zarządzaniu i udostępnianiu elektronicznych treści. Bez wątpienia biblioteki muszą stale dostosowywać swoje usługi do zmieniających się warunków i możliwości prezentacji cyfrowych zasobów, w których od pewnego czasu znaczącą rolę zaczynają odgrywać urządzenia mobilne.

\section{Bibliografia}

Gmiterek G., Kotuła S.D., A plikacje mobilne nie tylko w bibliotece, Warszawa 2017. Google Search. Webmasters. Mobile Friendly Websites, https://developers.google.com/ webmasters/mobile-sites/?hl=pl, [dostęp: 13.04.2017].

Kozieł K., Strona mobilna czy responsywna? Oto jest dylemat!, http://enzo.pl/2013/ 06/26/strona-mobilna-czy-responsywna-oto-jest-dylemat, [dostęp: 12.04.2017].

PageSpeed Insights. Wtacz kompresję, https://developers.google.com/speed/docs/insig hts/EnableCompression, [dostęp 21.08.2017].

Sprawdź czy Twoja strona internetowa jest dostosowana do komórek, https://testmy site.withgoogle.com/intl/pl-pl, [dostęp: 10.04.2017].

Test optymalizacji mobilnej, https://search.google.com/search-console/mobile-friendly ?hl=pl, [dostęp: 10.04.2017].

Topolska E., Strona responsywna to must have - Google przestało wspierać strony bez wersji mobilnych, http://www.mobiletrends.pl/strona-responsywna-to-must-have -google-przestalo-wspierac-strony-bez-wersji-mobilnych, [dostęp: 12.04.2017].

We Are Social, Digital in 2017 Global Overviev, https://www.slideshare.net/wearesoci alsg/digital-in-2017-global-overview, [dostęp: 10.04.2017].

${ }^{15}$ Zob. Google Search. Webmasters. Mobile Friendly Websites, [dostęp: 13.04.2017], https://developers.google.com/webmasters/mobile-sites/?hl=pl. 